\title{
ENTREPRENEURSHIP OF MIDWIFERY ACADEMY ALUMNI (A CASE STUDY OF SARI MULIA MIDIWFERY ACADEMY'S ALUMNI)
}

\author{
$1^{\text {st }}$ Sitti Khadijah, S.Pd., M.Pd ${ }^{1}, 2^{\text {nd }}$ Susanti Suhartati, SST., M.Kes ${ }^{2}$ \\ \{sittikhadijah@unism.ac.id ${ }^{1}$, susantisuhartati@unism.ac.id² \\ Universitas Sari Mulia, Indonesia ${ }^{1}$, Universitas Sari Mulia, Indonesia²
}

\begin{abstract}
Workforce unemployment of fresh graduates from vocational high schools and universities in Indonesia is still high. To face the problem, the government instructs Entrepreneurship Education subject to be taught at university levels. This study has purpose to find out the entrepreneurship of 70 Sari Mulia Midwifery Academy's alumni two years after graduation using descriptive qualitative method. The results of the study shows that of the alumni, $77 \%$ have jobs, $87 \%$ have jobs in their competency area, $47 \%$ become entrepreneurs, $39.06 \%$ have jobs and become entrepreneurs, $64 \%$ become entrepreneurs to get more income, $43 \%$ become entrepreneurs more than six months to a year after graduation, $67 \%$ become entrepreneurs in trading and $64 \%$ earn five hundreds to a million rupiahs per month from their entrepreneurial business. Thus, this study shows that as aimed by Entrepreneurship Education subject, becoming entrepreneur is chose by Sari Mulia Midwifery Academy's alumni in dealing with unemployment.
\end{abstract}

Keywords: entrepreneurship, midwifery alumni, entrepreneurship education

\section{Introduction}

With the population of around 260 people, Indonesia is the fourth most populated country in the world (after China, India and United States). The country also have young age population because about half of Indonesia's population are under 30 years old of age. Thus, if the two factors are combined, Indonesia will be a country of big workforce power (BPS, 2018).

Unemployment or jobless is a term given to a person who has no job, is looking for a job, or work only two days in a week, or someone who is looking for a proper job. Unemployment happens commonly because the working force or the number of people who look for jobs are not equal with the number of job available. The number of unemployment in Indonesia has decreased this past three years. Despite this fact, the unemployment at the urban area in Indonesia is significantly higher than at the rural areas. It is also interesting to point out that the gap between urban and rural unemployment widened over the past four years because rural unemployment has declined more rapidly than urban unemployment. The explanation for this 
is that many rural people move to the cities in search of employment opportunities. Indonesia has quite high unemployment of the workforce age 15 to 24 years old when fresh graduates from vocational high schools and universities are hard to get jobs in national employment market. Meanwhile, relatively small number of women work in formal sector in Indonesia. Only half of women who are in working ages are employed in formal sectors in Indonesia. There are two basic explanations about the matters, first, the tradition or the culture of women in Indonesia to stay at home and take care of the family especially after giving birth, and second, the gender unequal where Indonesian women tend to work in informal sectors (Indonesia-Investment, 2018).

Currently, the availability of midwives is over of the numbers that are necessarily needed by Indonesian. Many midwifery schools that graduate big numbers of midwives every year is one of the causes of over supplied. To add into this, the job vacancy to be midwives as civil servants that is opened by Indonesian government is getting smaller. Another challenge faced by the graduates from midwifery schools is to have the midwife's license paper or Surat Tanda Registrasi (STR). They need the paper not only to apply for jobs as midwives but also if they want to open their own private practice clinic. The paper can be gotten when they complete their education, graduate, and then pass the competency exam. At the other side, there is a problem of the distribution of midwives so that some places at the rural areas are still lack of midwives, especially places out of Java island such as in Ambon, East Nusa Tenggara, West Nusa Tenggara, Kalimantan and Sulawesi (JPNN, 2016). At the year of 2017, the number of midwives in Indonesia is 198.110. They work mostly in Puskesmas (Community Health Centers) and causes the over number of midwives working in the facilities of $81.85 \%$. In South Kalimantan province itself, there is an over number of midwives working in the Community Health Center of $94.76 \%$ or 49.460 midwives (Kemkes, 2018).

The midwifery training programs in Indonesia are in the form of academic and professional training held in higher education Institutions at Diploma III (three years program), Diploma IV (four years program), Bachelor Degree and Masters Degree programs in Midwifery. As one of Midwifery Programs in the country, Diploma III in Midwifery which is called Akademi Kebidanan or DIII Kebidanan is the most favorite and affordable program attended by Indonesian female students. It is the minimum education required for a female Indonesian to work as a midwife. The program aims to produce graduates who are capable of doing routine and contextual jobs, independently or with collaboration, and able to do supervision and guidance based on their managerial skills. After becoming a program in higher education in 1996, there have been more than 750 Diploma III Midwifery programs running through out Indonesia. They are either in the form of a school called Akademi Kebidanan (Midwifery Academy) or a study program called Program Studi DIII Kebidanan (Diploma III in Midwifery) under a Faculty of Health Sciences or a Health Sciences Institute (MOH, 2011).

Midwifery services is an integral part of health services that focused on women, babies and newborn. A midwife provides services based on her role, job and function according to the letter of decision from Ministry of Health No. 900/2002 about Midwife's Registration and Practice. A midwife can work at various levels of health facilities such as at the village, Puskesmas (Community Health Center), maternity clinic/hospital, general hospital or open a private practice as private practiced midwife (Arifin, 2011). The midwives who have entrepreneurial business in the form of private practice can create job opportunities, especially in health field and can help solve the problems of unemployment (Priyadi, 2011).

The establishment of educational environment conductive to student learning and development is essential if an institution of higher learning is to achieve its educational 
purposes since the primary purpose of education has always been to promote change, both in individuals and in society (Dean, 2009). In their responds to reduce the number of employments, the government of Indonesia has instructed entrepreneurship education course to be given at college level in Indonesia. It is also done in order to create competent young entrepreneurs with their bachelor's degrees. Entrepreneurship education course is expected to give students knowledge and skills of entrepreneurship when they graduate. Entrepreneurship education is central thing associated with student entrepreneurship. Research findings have shown that the role of college by providing holistic support can help form students' entrepreneurial motivations. Universities' role in motivating their students to be entrepreneurs is very important to grow the numbers of young entrepreneurs (Budiarti, 2012).

Entrepreneurship is the mental attitude and the nature of the soul which is always active in trying to advance the work of one's devotion in order to increase revenue in his or her business activities. Entrepreneurship is the recognition, evaluation and pursuit of opportunity in diverse contexts. It is expressed in observable behavior such as founding an organization (profit or not profit) or leading a project within an organization to pursue an opportunity (Pendergast, 2003). According to Carol Noore, the entrepreneurial process is started by having innovation which is influenced by some factors that come from inside or outside of the person, such as education, organization, culture and the environment (Tando, 2013). According to Amaran (2015), four motivating factors that relates to become entrepreneur are background, attitudes, motivations and skills. Entrepreneurship is also formed for a person through education or training. Entrepreneurship relates to the behavior of taking initiatives and organizing resources to the risks and failures. Entrepreneurship is the creative and innovative abilities to create things that are useful for oneself and others as well as the ability to face problems and use the chances. The advantage of someone who do entrepreneurial work is to have freedom to actualize the potency they have. There are many entrepreneurs who are successful to manage their businesses because they make them as their hobbies (Rusdiana, 2014).

As ordered by Indonesian government, the midwifery entrepreneurship education subject is presented at the Midwifery Academy. It is given to improve midwifery students' motivations and removes the presumption that entrepreneurship is a very difficult business. In general, this subject is also very necessary to strengthen the economy of Indonesia as well as to bring up the entrepreneurial creative that could create jobs and could help reduce unemployment. The subject not only gives theoretical foundation of the concept of entrepreneurship but also shapes attitudes, behaviors, and mindset to be an entrepreneur and an independent midwife (Arifin, 2011). In Sari Mulia Midwifery Academy Banjarmasin, the midwifery entrepreneurship education subject is presented to the students at the final year of their study. The students are expected to get the knowledge and skills of being entrepreneur when they graduate, not only as an alternative job choices, but also as a survival strategy to face the globalization (Sari Mulia, 2017).

This study is done as a part of tracer study of Sari Mulia Midwifery Academy Career Development Center (CDC) to gain information about Sari Mulia Midwifery Academy alumni's work and entrepreneurial situations. The research question is: What are the current job and entrepreneurial situations of Sari Mulia Midwifery Academy two years after they graduated?

\section{RESEARCH METHODOLOGY}


This study focuses on Sari Mulia Midwifery Academy Alumni's job and entrepreneurial situations two years after they graduated. Employing a descriptive qualitative method with an analysis of a survey by gathering information from 70 midwifery alumni of 171 alumni (41\%) who were graduated in 2016. The instruments used were alumni survey questionnaire in google form and list of questions that alumni answered by phone interview and whatsapp application. This questionnaire was created to be simple and focused on the information about alumni current jobs and entrepreneurial situations after they graduated. The interview and questionnaires were done in Indonesian language to avoid misinterpretation of the questions. After the data of this study have been collected, they were processed to the data reduction, coded and tabulated. Data analysis was done using descriptive statistic which is to describe the data without making the generalization of the research results. The data were then verified and displayed and finally, conclusions were drawn based on the available data and supporting data of this study.

\section{RESULT AND DISCUSSION}

The results of the study are provided along with the discussion of each research question can be seen in figures below.

The current job situations of Sari Mulia Midwifery Alumni can be seen in figure 1 below:

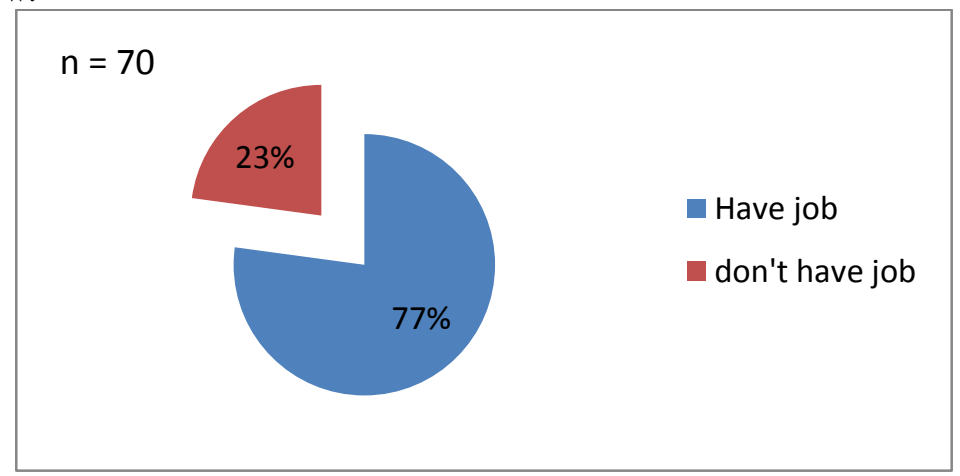

Fig.1. Sari Mulia Alumni’s current job situations

The research question of the linearity of the alumni job with their competency area (midwifery) can be seen on Figure 2 below: 


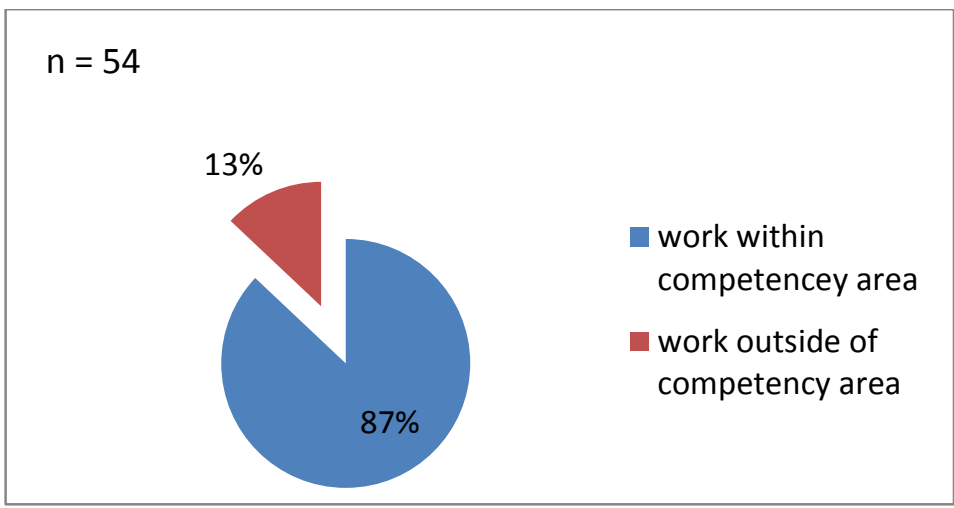

Fig.2. Job linearity with competency area (Midwifery)

The research question of having an entrepreneurial business can be seen on Figure 3:

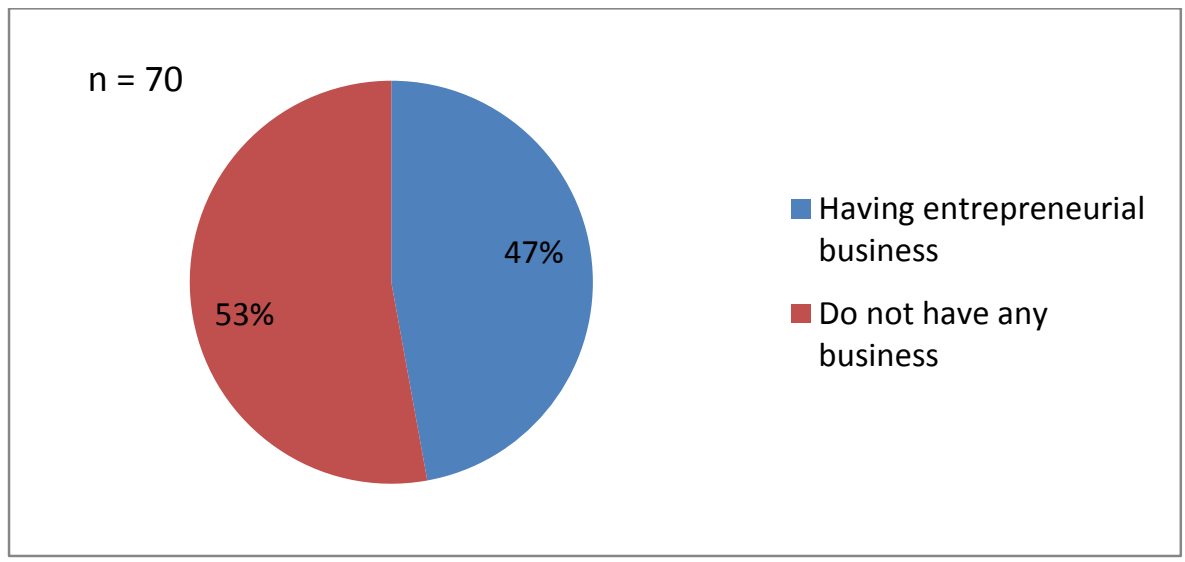

Fig.3. Having entrepreneurial business

The job and entrepreneurship situations of Sari Mulia Midwifery Academy's alumni can be seen on Figure 4 below: 


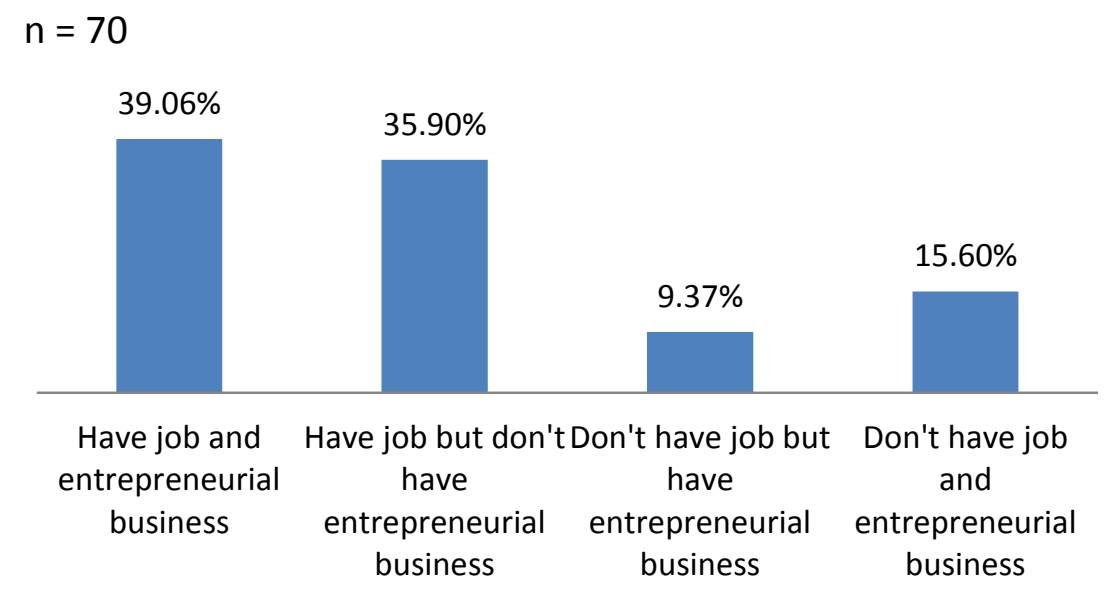

Fig.4. Job and entrepreneurial situations

The research question about the reasons of the alumni's for having entrepreneurial business can be seen on Figure 5: 


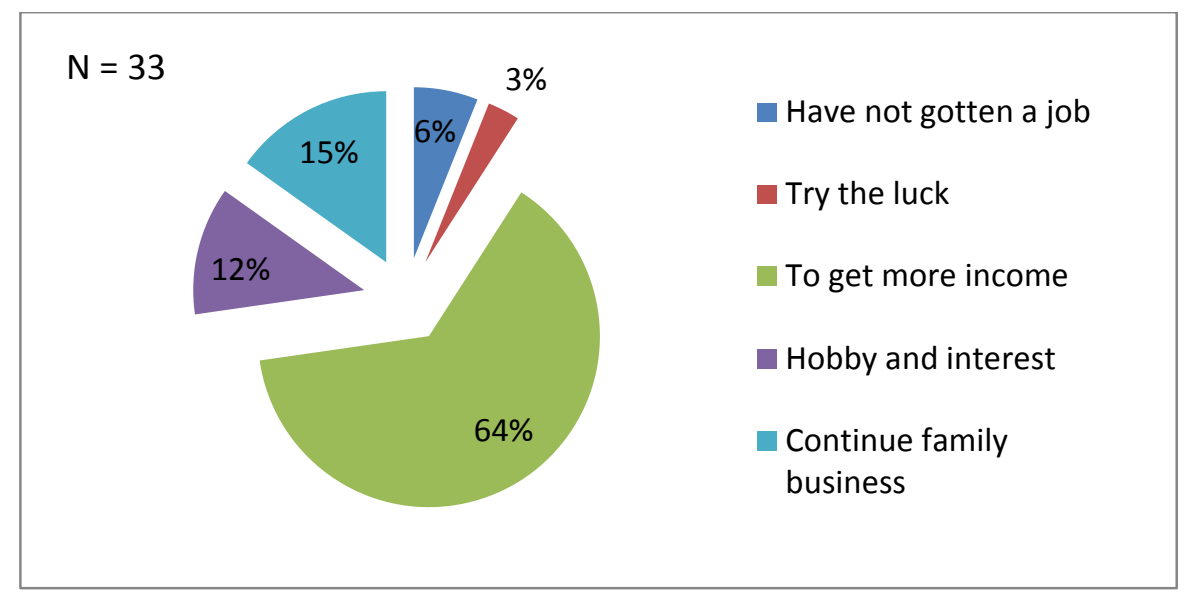

Fig.5. Reasons to have entrepreneurial business

The research question of the time Sari Mulia Midwifery Academy's alumni started their entrepreneurial business can be seen on Figure 6 below:

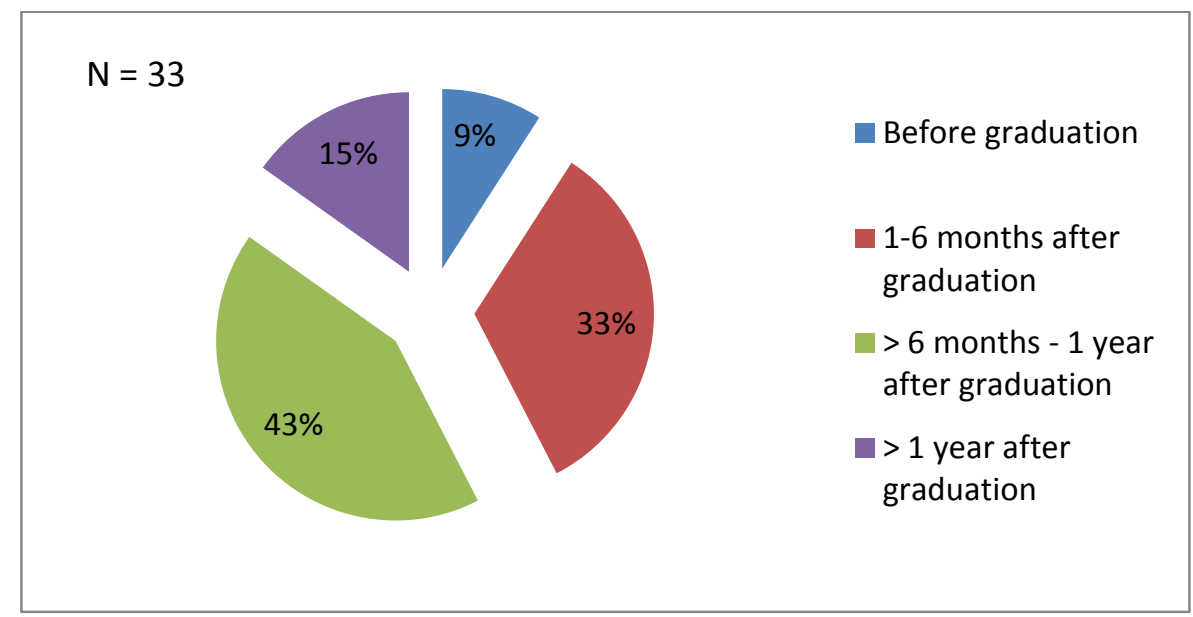

Fig.6. The time alumni's entrepreneurial business started

The research question of the types of entrepreneurial business that Sari Mulia Midwifery Academy's alumni have, can be seen on Figure 7: 


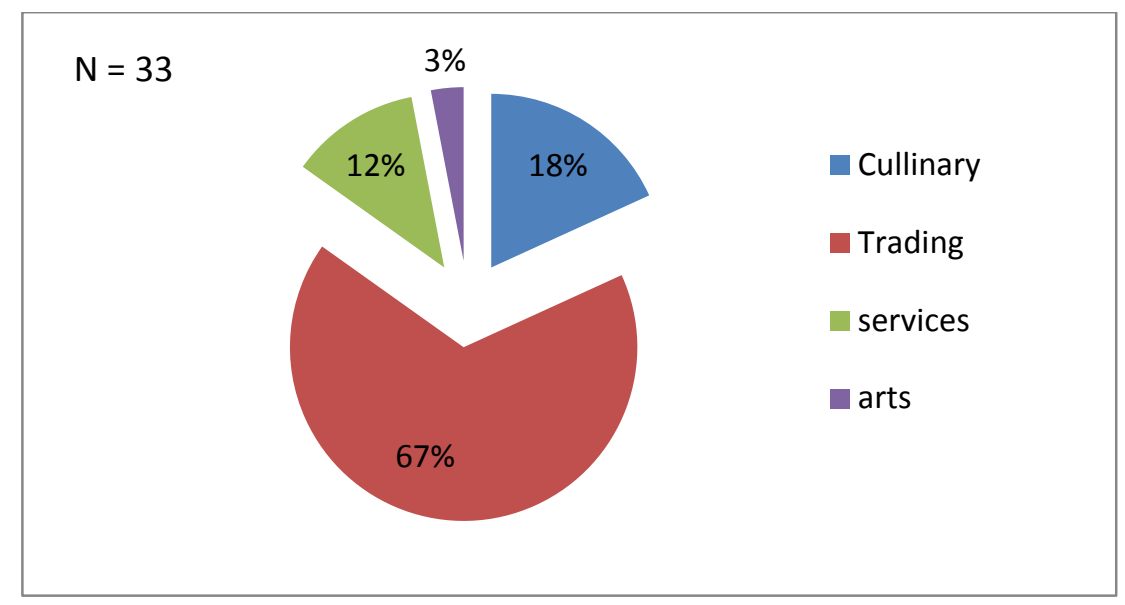

Fig.7. The types of entrepreneurial business

The research question about the income that Sari Mulia Midwifery Academy's alumni got from their entrepreneurial business can be seen on Figure 8 below:

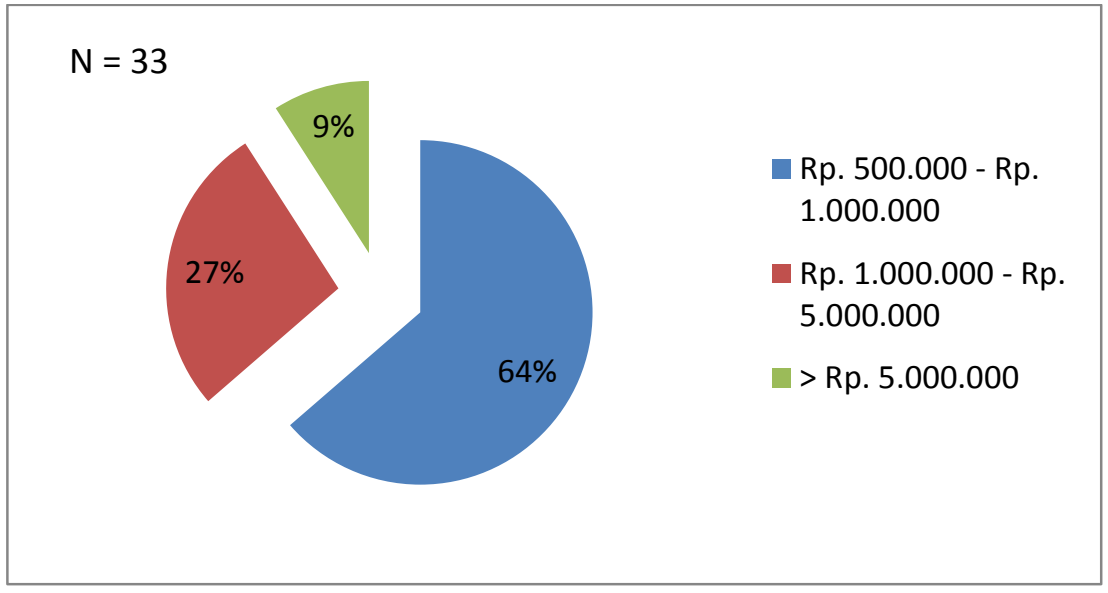

Fig.8. The Income from entrepreneurial business

The results of this research shows that $77 \%$ of Sari Mulia Midwifery Academy's alumni have job 2 years after their graduation. The cohort of alumni who were graduated in 2016 was taken because during the 2 years period, the alumni of an institution usually have had experience in the transition to the world of work or have had working experience. The 2 years period, is also not too long time after their graduation, so their information can contribute to the course that they experienced (Syafiq, 2016). The study shows that most of Sari Mulia Midwifery Academy alumni are employed. Their employments are good inputs for the midwifery Academy because it shows that the institution is quite successful in running their education to link and match with the world of working. 
In the study, $87 \%$ of Sari Mulia Midwifery Academy's alumni have job in their competency area. This means that most of the alumni prefer to apply and work in the field of health either as midwife or as health care providers.

The percentage Sari Mulia Midwifery Academy's alumni have entrepreneurial business is $47 \%$ which shows that almost half of the alumni taken as the sample applied the knowledge and skills they got at their college from Entrepreneurial Education subject. This is supported by the alumni answers in the interview that they had been taught about entrepreneurship when they studied at the midwifery academy.

The result that $39.06 \%$ of alumni have jobs as well as be entrepreneurs shows that the Midwifery Academy's alumni have motivation to have another job which is becoming entrepreneurs. This finding is supported by the other finding of this research that $64 \%$ of them have the reason being entrepreneurs in order to get more income. This is reason is supported by supporting data from the interview that $66 \%$ of the alumni who work in their competency area, work as non-permanent employees as TKS (tenaga kerja sukarela) or tenaga kontrak at the community health center or a hospital owned by government. Based on the interview, working as a non-permanent employee in a government health facilities especially as TKS can earn only from two hundred thousand to six hundred thousand rupiahs. Some of them even do not get monthly salary and will be paid if they get a patient to care. The alumni who work as tenaga kontrak at the community health centers earn from one million to two million rupiahs and the alumni work at the government hospitals earn from one point five million to two point one millions rupiahs. All of the alumni's income in this research is still below the UMK (Upah Minimum Kabupaten) or the district minimum salary in Indonesia, especially in South and Central Kalimantan area which is about two point five millions rupiahs (Dapur Pendidikan, 2018). Thus having an entrepreneurial business can help Sari Mulia Midwifery Academy's alumni to get more income.

The research found that $43 \%$ of Sari Mulia Midwifery Academy's alumni who have entrepreneurial business started their entrepreneurship more than six months to a year after they graduated. This result showed that almost half the alumni took different decision than others and decided to use the resources they had around them for better benefits which are the traits of being entrepreneurs according to Huang and Knight (2017).

The entrepreneurship situations of Sari Mulia Midwifery Academy's alumni shown by the results of this research are that $67 \%$ of the alumni who have entrepreneurial business are entrepreneurs in trading. Based on the interview done, the alumni do on-line and off-line business trading for people's daily needs such as, food, cosmetics or fashions. The trading entrepreneurships were the businesses had by their families or the business they had when they were still college students.

The last research question given to Sari Mulia Midwifery Academy's alumni about their income from their entrepreneurial business found that $64 \%$ of the alumni have income five hundred to a million rupiahs per month from their entrepreneurial business. Based on the interviews, in average, the amount of money that the alumni get from their entrepreneurial business can sufficiently support their main income as health care providers.

\section{CONCLUSION AND SUGGESTION}

\subsection{Conclusion}

In the nutshell, this research shows that from the sample taken, $77 \%$ of Sari Mulia Midwifery Academy's alumni who were graduated in 2016 have worked. The study shows 
that most of alumni used as the research sample are employed. Their employments are good inputs for Sari Mulia Midwifery Academy because it gives the fact that the institution is quite successful in running their education to link and match with the world of working. This study shows that $87 \%$ of Sari Mulia Midwifery Academy's alumni have job in their competency area. $47 \%$ of the alumni have entrepreneurial business and $39.06 \%$ of alumni who have jobs also become entrepreneurs. Among the alumni who become entrepreneurs, $64 \%$ of them have the reason of becoming entrepreneurs in order to get more income. The research found that $43 \%$ of Sari Mulia Midwifery Academy's alumni who have entrepreneurial business started their entrepreneurship more than six months to a year after they graduated. $67 \%$ of them are entrepreneurs in trading, especially on-line and off-line business trading for people's daily needs such as, food, cosmetics or fashions. Finally, 64\% of the alumni have income five hundred to a million rupiahs per month from their entrepreneurial business. The results reflect that most of the Sari Mulia Midwifery Academy's alumni are employed in their competency area and become entrepreneurs. Thus, this study shows that as expected by Entrepreneurship Education subject taught to them, becoming entrepreneurs is one of the choices made by the midwifery academy's alumni after their graduation.

However, the simple and short questions given in this research in the form of closedquestion questionnaires using google form gave very limited answers from the alumni, although it was meant to be made so that the alumni were willing to answer the questions. The alumni's limited time and the internet or cellular service problems are the most common obstacles faced by the researchers because the alumni live in the district or sub district area so the phone and whatsapp application interviews were cut off a few times.

\subsection{SUGGESTION}

Based on the research findings, entrepreneurial education should be still considered as the good subject at the midwifery academy that can encourage the midwifery students to do entrepreneurial business after they graduated. Having entrepreneurial business will give benefit to the midwifery academy alumni. It will help to decrease the unemployment if they do not get linear jobs or as additional income sources for the alumni.

The finding of this research that Sari Mulia Midwifery Academy's alumni who have linear jobs but still do entrepreneurial business with the reason to get more income have raised a question; "What really motivates the midwifery alumni to do entrepreneurial business, is it because of their intentions to add for the salary that they get from their linear or midwifery jobs or because of other factors?". Thus, a further study can be done to answer it with bigger number of sample or another cohort as well as different methodology. Afterward, the findings of this study are expected to be useful as consideration for other researchers who want to conduct a similar research but in different area.

\section{REFERENCES}

[1] Amaran, M. A. Involvement of graduates in the field of entrepreneurship in Kuala Lumpur, Malaysia. International Journal of Liberal Arts and Social Science. ISSN:2307924X. www.ijlass.org (2015).

[2] Arifin, S. Kewirausahaan Kebidanan. Mitra Wacana Media. Jakarta (2011).

[3] BPS. Tingkat Pengangguran terbuka. https://www.bps.go.id (2018).

[4] Budiarti, Y., et al. Minat Mahasiswa Menjadi Wirausaha. Jurnal Dinamika Sosial Budaya Volume 14 Nomor 1, Juni 2012 (2012). 
[5] Dapur Pendidikan. Upah Minimum Provinsi dan Kabupaten. www.dapurpendidikan.com (2018).

[6] Dean, L.A. CAS Professional Standards For Higher Education $7^{\text {th }}$ Edition. The Council for the Advancement of Standards in Higher Education (2009).

[7] Huang, L., \& Knight, A. P. Resources and relationships in entrepreneurship: an exchange theory of the development and effects of the entrepreneur-investor relationship. Academy of Management Review, 42(1), 80-102. https://doi.org/10.5465/amr.2014.0397 (2017).

[8] Indonesia-Investment. Angka Pengangguran di Indonesia. https://www.indonesiainvestments.com (2018).

[9] JPNN. Jumlah Bidan Sudah Membludak. https://www.jpnn.com (2016).

[10] Kemkes. Profil Kesehatan Tahun 2017. www.pusdatin.kemkes.go.id (2018).

[11] MOH. Indonesian Midwifery Education National Curricula. Pendergast, W.R. 2003.

Entrepreneurial Context and Traits of Entrepreneurs. Proceedings Teaching Entrepreneurship to Engineering Students. http://dc.engconfintl.org/teaching/8 (2011).

[12] Priyadi, D. A. Kewirausahaan untuk mahasiswa Kebidanan. Trans Info Media (2011).

[13] Rusdiana. Kewirausahaan Teori dan Praktik. Bandung: CV PUSTAKA SETIA (2014).

[14] Sari Mulia. Panduan Akademik. Akademi Kebidanan Sari Mulia Banjarmasin (2017). [15] Syafiq, A. et al. Metodologi dan Manajemen Tracer Study. PT RAJAGRAFINDO PERSADA (2016).

[16] Tando, N. M. Kewirausahaan. In Media. Yogyakarta (2013). 